\title{
Hodnoty a hodnocení z pohledu psychopatologie a psychoterapie
}

\author{
Marie Lhotová
}

V současné psychologii existuji dva hlavní modely uspořádávání systému hodnot. Kromě známého hierarchického modelu využitelného $v$ prípadech, zkoumáme-li individuální hodnoty bez toho, že bychom zkoumali vztahy mezi hodnotami navzájem, existuje též model nehierarchický, nazývaný též kruhový či cirkulární,' který reflektuje komplementární i kontrární vztahy hodnot. V tomto rámci jsou v odkazech na psychopatologické kategorie definované v ICD X formulovány možnosti a meze psychoterapeutické intervence, která staví na integrovaném př́stupu s akcentem na logoterapii a existenciální analýzu. Strukturu textu pomohli vytvořit studenti oboru Etika v sociální práci Teologické fakulty Jihočeské univerzity svými formulacemi definic hodnot, razením hodnot a hledáním a formulováním otázek a odpovědí. Tyło jsou pak konfrontovány s literárními odkazy. Další část textu vychází z výsledkủ klinicko-psychologické praxe autorky.

\section{K definici}

Vymezit, co je hodnota, a sestavit své hodnoty hierarchicky i kruhově dostali za úkol studenti 2. ročníku magisterského studia oboru Etika v sociální práci na TF JU na začátku výuky předmětu Psychologie hodnot. V rámci dvousemestrální výuky si pak své koncepty dotvářeli. Tato sonda do problematiky si neklade za cíl splňovat kvantitativní měřítka ani zobecnění poznatků o hodnotách, slouží jen k vytvoření představy prostoru, ve kterém se téma hodnot u vysokoškolských studentů může objevit.

Není překvapivé, že většina definic hodnot začínala slovy: Hodnota je něco... Něco, čeho si vážíme, co je žádoucí pro jednotlivce i skupinu a vede člověka k definování cílů, norem i k očekávanému chování a jednání. Něco, co je pro člověka důležité, důležitý aspekt života, který je nenahraditelný. Něco, co je cenné, např. co se považuje za morálně správné nebo špatné, dobré či zlé, a to v oblasti duševní, sociální a fyzické. Něco, co je pro člověka důležité v osobnostním rozvoji. Něco, co si chráníme a chceme zachovat. ${ }^{2}$

Snaha studentů o definování vyúst'uje v podstatě ve formulaci Kluckhohna, ${ }^{3}$ který vymezuje hodnoty jako explicitní nebo implicitní koncepci žádoucího, která ovlivňuje výběr jednotlivce nebo skupiny z dostupných modů, prostředků a cílů akcí. Přiblížili se též konstatování Maxe Schelera v odkazech na emoční složku hodnot v tom, že výška hodnoty je určená emocionální odezvou, a Franklově výroku, že hodnota je nejlepší možnost situace. Konstatování V. E. Frankla, že všechny hierarchie hodnot mají jedno společné, a to je život jako absolutní hodnota, bylo ve studentských odpovědích přetransformováno do hodnoty zdraví.

1 Srov. Karel HNILICA, Konflikt hodnot a kvalita života, Čs. psychologie 44/2000, s. 385-403.

2 Semináře Psychologie hodnot 2010-2013, obor Etika v sociální práci, 2. ročník.

3 Srov. Jan PAYNE a kol., Kvalilta života a zdraví, Praha: Triton, 2005, s. 296. 


\subsection{Podoba a smysl hodnot}

Jako výstup bylo možné vytvořit 8 skupin, které byly při definování zásadní: Hodnoty jsou tím, (1) co nám určuje směrování životě, vyjadřuje cíl, čeho chceme dosáhnout, co je základním prvkem, stavebním kamenem, měřítkem věcí (hodnota je prostředek a zároveň cíl, pomocí kterého určujeme směr svého života; dle hodnot se řídíme a k něčemu směřujeme; něco, co ukazuje, jakým směrem by měl člověk ubírat své jednání a co mu pomáhá se rozhodovat; hodnoty určují naše cíle a cestu, kterou se v životě ubíráme); (2) co konkrétně vede, určuje a ovlivňuje a) chování a rozhodování (hodnota je subjektivně objektivní zjištění cílového objektu, který vede člověka k určitému jednání a chování; podle hodnot se člověk rozhoduje, jak jednat; hodnota je preference člověka $\mathrm{v}$ průběhu života), b) myšlení (něco, čeho si člověk váží a na čem staví názory), c) emoce (něco, co člověk pocit'uje jako dobré nebo zlé), d) postoje (to, co člověk považuje za nejdůležitěǰ̌í měřítko všeho ostatního), e) motivace (hodnota zaměřuje, energetizuje a udržuje chování); (3) co vyjadřuje vztah (hodnota je nevyčíslitelný, nezcizitelný atribut určité věci, činu, vztahu); (4) co vyjadřuje úsilí (něco, za čím člověk usilovně jde; něco, k čemu je třeba napnout životní úsilí); (5) co vyjadřuje vưli (něco si odřeknout; udržet, co pro jednotlivce má význam, a to takový, že je schopen se něčeho vzdát; pro hodnoty je člověk ochoten něco obětovat; něco, na čem je schopen dále pracovat, aby toho dosáhl a udržel si to; (6) co vytváŕí orientaci (hodnota je něco, co člověku pomáhá být „lepším člověkem“, co popohání, čeho si člověk váží a co udržuje, něco, co pomáhá v životě a je osou jeho činění); (7) co vede ke smysluplnosti (dává smysl životu; hodnota je smysl života; hodnota je to, co k naplňování tohoto smyslu potřebuje další životní hodnoty, co překračuje lidské putování, v tomto smyslu jsou hodnoty nenahraditelné); (8) hodnota může být i vlastnost (čestnost, pravdomluvnost, pracovitost, svědomitost, obětavost, dobro).

Dále bylo studenty často zmiňováno přehodnocování a změna hodnot v průběhu života pod vlivem určitých událostí včetně tranzitorních změn $\mathrm{v}$ různých věkových etapách života člověka. Jako vliv na hodnotový žebříček zmiňují studenti výchovu a štěstí v životě a možnosti člověka jako takové.

\subsection{Hierarchie hodnot a jejich vztahy}

Dle využití kombinace hierarchického a cirkulárního modelu při práci s hodnotami byl v průzkumu získán přehled hodnot $\mathrm{v}$ hierarchii a ve vzájemné korelaci. Dle počtu odpovědí jsou shrnuty hodnoty v tomto pořadí: (1) zdraví blízkých a zdraví vlastní; (2) rodina, spokojenost $\mathrm{v}$ rodinném životě, spokojení rodiče, vzájemnost a soudržnost členů, rodinné prostředí, bydlení, domov; (3) partnerství, prátelství, dobré vztahy s lidmi, láska, podpora, dávání a príijímání, respekt, úcta, souznění; (4) společenství a jeho dobro, jistota, demokracie; (5) zaměstnání, vzdělání, smysluplnost práce, seberealizace, kompetence, úspěch, seberealizace, vlastní růst, ambice; (6) svoboda, nezávislost, hrdost, odvaha; (7) empatie, pochopení, porozumění, solidarita; (8) pravda, upřímnost, fér jednání, spravedlnost; (9) peníze, majetek, vlastnictví; (10) stopy člověka, které svým životem zanechává, angažovanost člověka v životě i ve smrti; (11) schopnost být prospěšný; (12) možnost poznávat, představivost, tvořivost; (13) dobré podmínky pro život (sociální stát), žít život, aby byl smysluplný a plnohodnotný; (14) víra, důvěra, spiritualita; (15) pravda, svědomí, čestnost, pokora, obětavost; (16) radost.

Ve srovnání s 36 univerzálními hodnotami rozdělenými do 4 skupin hodnot osobních, sociálních, morálních a kompetenčních, které uvádí ve své klasifikaci Milton Rokeach, ${ }^{4}$ je výčet hodnot studentů paralelní. Uvedený průzkum ukazuje okruh možností zabývat se studiem hod- 
not u vysokoškolských studentů. Zkušenosti z psychoterapie psychicky nemocných vykazují při zmínkách o hodnotách formulační i obsahové těžkosti. Tato skutečnost souvisí pravděpodobně s kontextem psychických obtíží, které zasahují nepříznivě do identity člověka a jejichž průvodním pocitem je ohrožená vlastní hodnota. V této souvislosti hledáme vztah identity a hodnot. Zvláštní místo zaujímá problém hodnocení. Jedna z prvních otázek je, zda, event. jak a proč $\mathrm{v}$ psychoterapii s hodnotami a hodnocením pracovat.

\section{Hodnoty v psychoterapii. Role hodnotového systému a hodnocení v psychoterapii}

Cakirpaloglu ${ }^{5}$ uvádí dva názory na psychoterapeutickou intervenci u hodnot. Jedním je nezbytnost práce $\mathrm{s}$ hodnotami, zvláště tehdy, objevují-li se v individuální struktuře hodnoty, které narušují fungování osobnosti, nebo jeví-li se psychoterapie hodnot účinná v rámci obecného uzdravování psychicky narušené osobnosti (Alfred Adler), kdy při absenci pohledu na realitu hodnoty člověka tyranizují. Druhým názorem, za jehož představitele je považována humanistická a existenciální psychoterapie, je odmítání jakékoliv psychoterapeutické intervence v oblasti pacientových hodnot. Poukazuje na pojem lidské svobody a sebedeterminace individuálního vývoje, která předpokládá suverenitu člověka nad vlastní osobností a všemi jejími aspekty, kam přirozeně spadá i systém hodnot. Při bližší analýze se však ukazuje, že jsou zde psychoterapeutickou intervencí myšleny přímé zásahy, které jsou představitelné moralizátorským přístupem k psychicky narušenému jedinci, nebo snaha o přenos hodnotových struktur psychoterapeuta, které on sám považuje za dobré, bez ohledu na kontext pacientova života a jeho dosavadních zkušeností. Psychoterapeutická intervence by se takto mohla podobat nevyžádané pomoci a jako taková se neoprávněnou stát.

\subsection{Hodnoty v existenciální analýze}

Existenciální analýza a logoterapie jako jedna z představitelů humanistických př́istupů v psychoterapii pracuje s hodnotami velmi intenzivně v rámci osobní existenciální analýzy. V psychoterapeutickém rámci vychází ze zážitku, příp. směřuje k zážitku vyživujícímu základní hodnotu vyjádřitelnou slovy "jsem rád, že žiji“. V těchto slovech se jedinec setkává s hodnotou. Hodnota života je základní hodnotou připravenou k realizaci v přijímání života, jakkoliv náročného, jakkoliv omezeného. $V$ tomto smyslu je hodnota chápána jako stav otevřenosti vůči světu. Otevřenost vůči světu dovolí, aby se hodnoty žily. Teprve jestliže člověk žije své hodnoty, tj. ty, kterým skutečně říká „ano“, uskutečňuje sám sebe. Tím přecházíme od základní hodnoty k hodnotě nazývané hodnota vlastní.

\subsubsection{Vlastní hodnota}

Vlastní hodnota (Selbstwert), kterou definují podobně Längle, Frankl, Kruse či Kastová6 jako biologicky preformovanou emoci, která se vyvíjí a diferencuje v každém jedinci ve vztahu k vazebným osobám do značné míry nezávisle na kultuře, může být chápána jako primární emoce. Proto klinická pozorování směřují k tomu, aby pocit vlastní hodnoty byl studován jako svébytná emocionální oblast. Pocit vlastní hodnoty tvoří základ zkušenosti identity. Životní krize, deprese, úzkosti i (psycho)somatické obtíže způsobují, at’ už jsou event. i kompenzovány grandiozitou nebo arogancí, že se člověk cítí nejen špatně, ale také nehoden toho, aby vystupoval jako partner v kontaktu. Jestliže chce tento pocit překonat, překonává ho obrannými mechanismy, které mo-

5 Srov. Panajotis CAKIRPALOGLU, Psychologie hodnot: Přehled pro humanitní obory, Olomouc: Votobia, 2004, s. 399.

6 Srov. Verena KASTOVÁ, Být sám sebou: Pocit vlastní hodnoty a zkušenost identity, Brno: Emitos, 2012 , s. 30. 
hou zcela zaplnit zdravý prostor jedince a stát se osobnostní výbavou, kdy už člověk nenachází náhled na původ těchto obranných mechanismů. Takto je v mnoha zdrojích psychoanalytické literatury popisován vznik poruch osobnosti i úzkostných a jiných neurotických poruch.

Zjednodušeně řečeno, vlastní hodnota označuje pocit hodnoty vlastní osoby. Obraz vlastního já vzniká ohodnocením zevnitř a zvenčí. To, co je vlastní, jedinečné, potřebuje člověk na ochranu sebe sama. Pokaždé, když odmítne to, co v něm vězí, vydává vlastní hodnotu v ohrožení. V této souvislosti se objevuje téma hranice. Určení hranice je ztíženo nebo není možné, když je ohroženo „já“. Je-li na scéně toto ohrožení, je ohrožen také vztah, nebot' jedině ,já“ se může vztahovat. Následně hrozí to, že nevztahující se člověk není okolím přijat. Když člověk cítí závislost nebo asymetrii ve vztahu a když se chce ukázat v dobrém světle, zalíbit se, ale nemá zdroje pro posílení vlastní hodnoty, musí pak pracovat na tom, aby neodhalil své nedostatky a hodnota jeho osoby v očích druhých neutrpěla.

Indukci vlastní hodnoty je možné v psychoterapii zvnitřnit pomocí tří kroků. Tento proces začíná posíleným vnímáním sebe sama, což znamená v podstatě reflexi vlastní osoby zacílenou k možnosti vzít se vážně, navázat dialog se sebou a vztah k sobě. Následuje vstup do vztahu se svými hodnotami a nakonec zaujetí vlastního postoje k sobě či stanoviska k dění týkajícího se sebe samotného.

\subsubsection{Osobně-existenciální základní motivace}

Motivy činnosti jsou dány hodnotami, jejich získáváním, chráněním atd.7 Existenciální analýza pracuje s životními motivacemi, které pomáhají podrobit pacientovy hodnoty analýze, a to počínaje tématem základní hodnoty existování k životu. Konkrétně jde o směřování ke kladné odpovědi na tři základní otázky vztahující se k motivaci. Důležitým aspektem je přitom skutečnost, že hodnota má vždy subjektivní význam, jak je ostatně zdůrazňováno u mnoha předních axiologů (např. Perry, Buczyńska-Garewiczová, Svanda). ${ }^{8}$ Hodnota je to, co je jako hodnotné prožíváno, co je výtvorem konkrétního prožívání jedince. Zájem je pak bezprostředním přiznáním hodnoty, kterou tvoří hodnota sama. Buczy-Garewiczová v tomto smyslu hovoří o existenciálním zakořenění hodnoty v psychice. ${ }^{9}$ Výše uvedené otázky po motivaci vycházejí z prvního předpokladu, kterým je možnost člověka žít v podmínkách, jež jsou mu dány. Dalšími předpoklady je pak nejen možnost, ale chtění, tedy skutečnost, zda chce v daných podmínkách žít, přičemž chtění je v existenciální analýze chápáno jako přitakání hodnotě. Třetí motivací je smět žít a činit tak, jak člověk chce, jaký člověk je, a přebírat za to zodpovědnost, aniž by jedinec sledoval a odpovídal na požadavky, jakým ho chtějí mít jiní lidé. Konečným bodem, čtvrtou motivací, je pak odpověd' na otázku po tom, jaký člověk má být, aby byl jeho život smysluplný.

Existenciální analýza nebude učit pacienta novým či jiným hodnotám, ale pomůže propracovat se $\mathrm{k}$ tomu, na čem mu nejvíce záleží, za čím je schopen stát a za co může převzít zodpovědnost. Dle dnešního pojetí existenciální analýzy je člověk skutečně svobodný k nalézání smyslu tehdy, když jsou uvedené čtyři motivace naplněny, tj. když může danou situaci přijmout, když je osloven hodnotou a chce ji, když si své jednání dokáže eticky zodpovědět na základě svědomí a rozeznává povahu výzvy v daném čase a v dané situaci představitelnou v podobě „tato chvíle je zde právě $\mathrm{k}$ tomu“.$^{10}$

7 Srov. Milan NAKONEČNÝ, Emoce, Praha/Kroměříž: Triton, 2012, s. 63.

8 Srov. tamtéž, s. 57-60.

9 Srov. tamtéž, s. 56.

10 Alfried LÄNGLE, Nalézt přitakání životu, Propsy 2/1997, s. 9-11. 
Z klinické praxe lze poskytnout řadu příkladů situací, kdy nejsou naplněny základní existenciální motivace a je třeba se zabývat postupně předpoklady plné existence, tj. přijetím, prožitím hodnoty a bytím sám sebou. Smysl psychoterapie potom spočívá v úkolu zabývat se též vlastní ohrožeností a tím, že člověk nedokáže přijímat, zabývat se zjevným nedostatkem hodnot, situací, kdy hodnoty má člověk zformulované, ale rezignuje na to, že by za nimi mohl jít. Člověk subjektivně vnímá jako nesmyslné, když prožívá nebo činí (1) něco, co nemůže přijmout (např. výchovné opatření), (2) něco, k čemu nemá žádný vztah (např. úkol), nebo (3) něco, o čem cítí, že by to vlastně neměl dělat, protože si to nedokáže zodpovědět. ${ }^{11}$ Existenciální analýza mluví o zážitku hodnoty, který znamená uchopit a zároveň být uchopený, a to v té jednoznačnosti, že se to týká konkrétní osoby a jejího situačního kontextu.

\subsubsection{Rámec rozeznávání}

Logoterapie a existenciální analýza kromě známého rozlišování hodnot tvůrčích, zážitkových a postojových rozlišuje a vysvětluje rámec hodnot všeobecných, individuálních a osobních. Všeobecnými hodnotami jsou myšleny hodnoty, které jsou typické pro většinu lidí ve všedních situacích. Tvořila je společnost v celé historii a vyúst'ují v tradice, zvyky, normy, obyčeje a zákony, at' už jsou dány společnými dohodami, pravidly nebo přikázáními Desatera. Po obsahové stránce jsou to např. spravedlnost, věrnost, láska, dobro či pravdomluvnost. Tyto hodnoty v podstatě nepodléhají času, jejich utváření a přetváření trvá mnohdy celé generace. Jsou to hodnoty, které dávají člověku orientaci. Mnoho společných (všeobecných) hodnot přebírá člověk do svého individuálního konceptu (dochvilnost, věrnost, pravdomluvnost), nikoliv však všechny. Individuální hodnoty se čas od času aktualizují, pokud ne, mají se aktualizovat. Osobní hodnoty jsou více či méně situační. Jsou případy, kdy člověk nemůže žít všeobecné ani individuální hodnoty, protože situace vyžaduje realizovat hodnotu jinou. Ačkoliv např. existují dopravní předpisy jako všeobecné hodnoty, člověk jako jedinec je uznává jako individuální hodnoty, ale nedodrží je v situaci, kdy veze v autě člověka s infarktem. Taková situace vyžaduje dát přednost hodnotě absolutní, tj. hodnotě lidského života.

\subsection{Koncept vnitřní ucelenosti a harmonie}

Cencini, jehož koncept práce s hodnotami je v psychoterapii využitelný, poukazuje na harmonii mezi intrapsychickými obsahy, kterou je třeba vytvářet v lidské psychice, a to se zřetelem též k nevědomé sféře. ${ }^{12}$ Jde o snahu docílit rovnovážného stavu mezi strukturálními obsahy já, tj. mezi potřebami, postoji a hodnotami. Předpokládáme, že v člověku působí energie vázaná na základní potřeby, ale také hybná síla, kterou mají ideály, v něž věříme. Za hybnou sílu autor považuje hodnoty. Jako ucelenou osobnost vnímá tu, jejíž postoje jsou inspirovány hodnotami, a přitom využivají energii jejích potřeb. Soulad mezi hodnotami a potřebami považuje za zdroj pro pomoc milovat člověka v Bohu a Boha v člověku. Spolu s Franklem se shoduje v akcentu na důležitost „bytí na cestě“ jako přijetí "progresivní harmonizace“ psychodynamických sil člověka. Hodnotám připisuje úkol usměrňování vlastního instinktivního života plného zmatků, ukazování cesty a současně působení silným tahem ve směru individuální cesty.

V psychoterapeutickém působení jsou známé mnohdy zásadní možné účinky „tahu“ hodnot, a proto jsou na ně kladeny jisté požadavky. Hodnota musí být transcendentální, náročná, přitažlivá (cenná). Hodnota při zřeteli k možnosti změn může pomoci zreorganizovat vnitřní život; jako taková musí být transcendentální, aby se člověk vyhnul všem pohodlným zredukovaným 
interpretacím. Jestliže tomu tak není, existuje nebezpečí, „že jde pouze o maskovanou verzi potřeb člověka“" ${ }^{13}$ Zároveň autor zdůrazňuje přijetí potřeb jako přirozených schopností a jako základního elementu pro lidské a duchovní zrání, jako cennou sílu, která podněcuje k jednání a dává našemu bytí nadšení typické pro „člověka, který žije“. ${ }^{14}$ Podobně jako u existenciální analýzy i v Cenciniho teorii lze vyčíst jako rizikový element a porážku v procesu realizace lidského jedince obecný nedostatek schopnosti pro vytvoření hodnot, a tedy životního smyslu. Funkční podstatu hodnoty lze v tomto kontextu zestručnit dle Cakirpalogla (2004) vymezením dvou behaviorálních celků. Jedním je podpora procesu adaptace člověka na fyzické a sociální podmínky, druhým pak proces individuálního růstu v překonávání vlastní existence. ${ }^{15}$

\section{Hodnocení}

Zvláštní místo ve vztahu subjektu k objektu má hodnocení. Stejně jako svoboda rozhodování patří i hodnocení k základnímu existenciálnímu vybavení člověka. Hodnoty lze vnímat jako výsledky, příp. měřítka hodnocení. Pojem hodnocení představuje vzájemnou propojenost s pojmem hodnota, kterou formuluje Scholl-Schaaf ${ }^{16}$ tak, že hodnota může být chápána jako abstrakce hodnocení, a naopak hodnocení jako prostorové a časové konkretizování hodnoty. Hodnocení je z tohoto pohledu aktuální vykonávání hodnot, tedy realizování modelu preferencí. Jeví se jako „složitý proces subjektu vůči objektu hodnocení, který je regulován druhem a intenzitou příslušné hodnoty“ ${ }^{17}$ Tuto definici lze rozvést v tom směru, že hodnocený objekt, mluvíme-li o lidské interakci, je zároveň hodnotícím subjektem, který se snaží o poznání, př́íp. pochopení hodnotového systému hodnotícího, aby mohl zaujmout stanovisko k hodnocení, příp. korigovat vnější projevy dle předpokládaného účinku na hodnotícího. Jde tedy o sociální percepci, dále apercepci jako připravenost interpretovat na základě minulé zkušenosti a konečně valorizaci jako určení hodnot(y), které jsou při hodnocení ve hře. V hodnotícím procesu pak může u různých lidí převažovat dle lokalizace vlivu (locus of control) (Julian B. Rotter) hodnota nezávislosti nebo hodnota pozitivních zpětných vazeb od druhého. Hodnocení je tvoření dané vztahem i tvořením vztahu a jako takové může být interpersonálně pozitivním prvkem, ale stejně tak může být prvkem likvidačním.

\subsection{Hodnocení v psychoterapii}

V psychoterapeutickém dění platí pro psychoterapeuta obecně zásada nehodnotit. Téma hodnocení je však přítomno více či méně intenzivně alespoň z hlediska pacienta, protože pacient se cítí hodnocen především proto, že v etiologii psychických poruch jsou takřka pravidelně přítomny nespecifické příznaky, jako je např. nejistota, více či méně nahlížené nižší sebehodnocení, úzkost, strach. S těmito jevy je třeba se v psychoterapii konfrontovat. Redukce doprovodných nepř́ijemných emocí často vede přes umělé udržování zpětných vazeb vykazujících pozitivní hodnocení, o které si pacient přímým či nepřímým, často manipulativním způsobem žádá. Strach z hodnocení často představuje závažnou překážku v psychoterapeutické práci, protože pacient se cíleně zaměří na to, aby byl dobře hodnocen terapeutem, takže cesta k označení či pojmenování obtíží je náročná.

\footnotetext{
13 Tamtéž, s. 128.

14 Tamtéž, s. 130.

15 Srov. Panajotis CAKIRPALOGLU, Psychologie hodnot: Přehled pro humanitní obory, s. 403.

16 Srov. Milan NAKONEČNÝ, Emoce, s. 61.

17 Panajotis CAKIRPALOGLU, Psychologie hodnot: Přehled pro humanitní obory, s. 399.
} 


\subsubsection{Hodnocení jako problém}

Hodnocení samo o sobě se stává problémem a demotivujícím prvkem, když se o člověku byt' i s nejlepším úmyslem rozhoduje. Potom ztrácí pocit, že může život v určité situaci přinejmenším spoluutvářet. Je-li člověk v určité situaci totálně kontrolovaný, pocit vlastní hodnoty mizí a dělá místo jiným emocím, např. agresi, vzdoru apod. Motivace může být hodnocením prohlubována, ale také redukována nebo ničena.

Zdá se, že obecně platí paralela agrese a ohrožení hodnoty. Tam, kde se objeví agrese, je tedy třeba zaměřit pohled na hodnoty. Stejně tak strach je přímým ukazatelem ohrožení hodnot. V depresi se ztrácí emoční vztah k hodnotám. Jestliže člověk žije hodnotu, které řekl „ano“, nestojí ho to tolik vitality, úsilí a vyčerpání. Na tomto základě lze pohlížet jak na depresi, tak i na stres a syndrom vyhoření. Převažuje-li významně a dlouhodobě pouze některá z hodnot známých z Franklova členění - tvưrčí, zážitková, postojová -, prvním ukazatelem je stres.

Diagnostika sama o sobě z hlediska pacientů často evokuje hodnocení a nutno přiznat, že tomu tak v podstatě je, nebot' stav pacienta je srovnáván s hodnotami zdraví. Psychodiagnostika je aplikovaná psychologická disciplína, jejímž základním úkolem je zjišt'ování, hodnocení a měření duševních vlastností a stavů, př́ípadně dalších charakteristik individua. ${ }^{18}$ Zejména při absenci náhledu na psychickou poruchu pacient často prožívá diagnózu problematicky, přinejmenším jako zaškatulkování, které je z jeho strany vnímáno jako ohrožení v tom, že mu nebude dovoleno se ze škatulky vymanit. Představa pacienta, že je neustále všemi hodnocen, je v psychopatologii velmi častá, mnohdy dosahuje svou nevývratností kvalit bludu. Je jistě představitelné, jak takovéto nastavení ovlivňuje kvalitu života.

\subsubsection{Hodnocení a sebehodnocení}

Řadu výzkumů týkajících se hodnocení a sebehodnocení realizovala na přelomu století Astrid Schützová. ${ }^{19}$ Jejich interpretací zjistila pro psychologii a psychoterapii důležité poznatky. $\mathrm{V}$ tomto ohledu poukazuje především na nepoměr mezi sebehodnocením jedince a hodnocením ze strany druhých lidí. Dále poukazuje na sebepřeceňování v sociální oblasti nebo destruktivně znehodnocující nedoceňování u lidí s nízkým pocitem vlastní hodnoty, kteří prožívají závistivé emoce zapříčiňující další znehodnocování. Poukazuje také na to, že vysoký pocit vlastní hodnoty může být budován „uměle“ v tom smyslu, že si člověk přisuzuje převahu tím, že nepřijímá druhé lidi jako rovnocenné, protože by se cítil ohrožený. Motivem je touha po tom, aby se jevil druhým jako osoba mocná, s vysokým pocitem vlastní hodnoty. Lersch ${ }^{20}$ (1962) mluví v této souvislosti o „pocitu svémoci“, který definuje jako pocit přesvědčení, že daný jedinec může ovlivnit situaci. Z hlediska uvažování hlubinné psychologie se vynořuje otázka, zda egocentrický sebevelebící pocit vlastní hodnoty, kterou mu ostatní potvrzují, protože to chce, skutečně vyplývá z oceňujících pocitů, nebo jestli nejde o grandiózní kompenzaci špatného pocitu vlastní hodnoty.

Dalším problémem je, zůstanou-li hodnoty pouze na racionální úrovni a nezvnitřní se, takže vznikají různá iracionální přesvědčení a požadavky typu „musím být za každých okolností ke všem hodný".

Dát možnosti psychoterapii, tzn. zacílit ji k vyvolání žádoucí změny v obtížích, které vyplývají z hodnotového systému pacienta, předpokládá pracovat na porozumění pacientovým hodno- 
tovým kategoriím a hodnotovému žebříčku na emoční i racionální rovině. Terapeutický zásah do systému hodnot se může odehrávat prvoplánově na rovině práce s mapováním hodnot, příp. analýzou hodnot a hodnotových stupnic, jak je popsáno zejména v kognitivně behaviorálním př́istupu. Druhou možností je nechat vystoupit a sledovat hodnoty v určitých souvislostech motivů, emocí a pocitů vztahujících se k životnímu příběhu pacienta. V obou směrech jde o práci na náhledu pacienta do vlastních hodnot a hodnotících procesủ. Přitom kognitivní procesy se odvíjejí individuálně a sledují citové a motivační vlastnosti. V obou směrech jde o složitou vnitřní reflexi opírající se prvotně bud' o emoce, nebo o racionální hledání a ujasňování hodnot. Prvním krokem při práci s emocemi je specifikace neadekvátních emočních reakcí, hledání jejich podstaty a hledání subjektivní logiky emocionálního prožívání. V rámci těchto kroků lze identifikovat hodnoty, které za těmito emocemi a následným jednáním stojí, hledat přičinu absurdního hodnocení, podstaty jednání v afektu a hledat shodu či neshodu s logikou rozumu. Pro eventuální změny je pak žádoucí valorizovat hodnoty stávající nebo sledovat cestu k hodnotám novým.

Při přímé psychoterapeutické práci s hodnotami Twokig a Crosby ${ }^{21}$ doporučují pacientům postupovat podle 7 kroků: (1) Rozlišit mezi tím, co se má, a vlastní svobodnou volbou. (2) Hodnoty pomáhají smysluplné cíle stanovit a hodnotně k nim směřovat. (3) Vymezit, na čem subjektivně záleží v různých oblastech života. (4) Stanovit význam jednotlivých hodnot. (5) Reflektovat, nakolik pacient svým chováním aktuálně naplňuje příslušnou oblast hodnot. (6) Volit bezprostřední cíle, které jsou v souladu s hodnotami. (7) Naučit se chovat tak, aby to bylo v souladu s vlastními cíli a hodnotami.

\section{Indikace pro terapeutickou práci s hodnotami}

Při psychoterapeutické práci se předpokládá vzájemná propojenost individuálních a skupinových hodnot. Skupinové hodnoty regulují chování a ovlivňují vědomí členů skupiny a individuální hodnotová produkce pak představuje nejdůležitější zdroj transformace stávajících hodnot skupiny. ${ }^{22}$ Mezi oběma - skupinovými a individuálními - hodnotami může dojít ke konfliktu, a stejně tak mohou vznikat konflikty na jedné z těchto rovin. Předpokládá se také, že konflikt hodnot je relativně trvalou charakteristikou osobnosti nebo skupiny. Jestliže je takový konflikt aktualizován, projevuje se ambivalencí či neschopností v oblasti rozhodování a následně závislostí, kdy člověk nadměrně potřebuje, aby za něho rozhodovali druzí. Následkem je submisivní chování doprovázené bezmocí a extenzivním strachem z opuštění. Z toho vyplývá přinejmenším jeho stálá potřeba podpory a ujištění, má-li dělat samostatná rozhodnutí. Takto potřebný jedinec naléhavě vyhledává společnost těch, kteří mu mohou poskytovat podporu a pomoc. Typicky se trvale a pasivně spoléhá na jiné osoby, které za něho mají činit rozhodnutí. Běžný je pak pasivní souhlas s přáním jiných osob, bázlivost i lísavost. ${ }^{23}$ Pokud jeho potřeba závislosti není uspokojena, snadno podléhá depresi nebo úzkostným stavům. Zpětné vazby, které takový člověk dostává, mnohdy neodpovídají realitě, nebot' jsou vystavěné na soucitu nebo vzdoru. Typickým znakem je, že takto postižené osoby těžko vyjadřují nesouhlas, což je ve vztahu k žitým hodnotám v souladu s tezí, že jestliže člověk žije určitou hodnotu, které říká „ano“, umí též říkat „ne“.

21 Srov. Ján PRAŠKO a kol., Hodnoty a kognitivně behaviorální terapie, Psychiatrie pro praxi 2/2014.

22 Srov. Panajotis CAKIRPALOGLU, Psychologie hodnot: Přehled pro humanitní obory, s. 377.

23 Srov. Ján PRAŠKO a kol., Psychické problémy u somaticky nemocných a základy lékařsképsychologie, Olomouc: Univerzita Palackého v Olomouci,

Lékařská fakulta, 2010, s. 176-177. 


\subsection{Přecenění či podcenění hodnocení}

Milivojević rozlišuje dvě obecné skupiny patologie hodnocení, ${ }^{24} \mathrm{kdy}$ jde o přecenění určité hodnoty, tedy hypervalorizaci, a podcenění hodnoty, hypovalorizaci. Oba typy znamenají, že se ve struktuře reakcí neobjeví emocionální reakce na danou hodnotu, která by byla adekvátní. Hypervalorizace způsobuje velmi intenzivní a dlouhotrvající reakci ve vztahu k narušení či ohrožení přeceňované hodnoty, $v$ emoční oblasti pak úzkost či strach vyvolávající situačně neadekvátní chování. Jako př́klad se nabízí přecenění hodnoty zdraví a z toho vyplývající stav ohrožení při hypochondrické poruše. Hypervalorizace sebeúcty a ohrožení sebeúcty vede k projevưm grandióznosti, vlastní důležitosti a jedinečnosti své osoby a zároveň přecitlivělosti na hodnocení. Týká se narcistické poruchy osobnosti, pokud osoba není brána jako originální a okouzlující. Hypervalorizace sexu vede např. k promiskuitním vztahům nebo deviantnímu sexuálnímu chování.

Hypovalorizace naopak představuje podcenění hodnoty nebo její ingnorování. Je představitelná tím, že adekvátní citová reakce vztahující se k určité hodnotě se neobjeví. Neobjeví se ani motivace k adekvátnímu chování v situaci, která může být nebezpečná. Př́ikladem opět může být hodnota zdraví a hazardování se zdravím nebo autoakuzační tendence, hypovalorizace sexuality objevující se v sexuální anhedonii nebo sexuální averzi nebo úzkostné či depresivní poruchy vztahující se k sebepodceňování.

\subsection{Inverze hodnotových kategorii}

Hodnoty v dané kultuře žádoucí a přijímané se v hierarchii hodnot jedince objevují až na konci hodnotového žebřičču a naopak, hodnoty nežádoucí jsou považovány za kladné. Odraz v chování člověka s takto nastavenými hodnotami vykazuje asociální charakteristiky, kdy zacílení na majetek, riziko, partu, alkohol či drogy ohrožuje hodnotu lidského života vủbec. Do tohoto rámce je zařaditelný i silný a kladný postoj ke smrti směřující k sebepoškozujícímu chování, vraždám či sebevraždám.

V kořenech psychopatologie může být kromě inverze hodnotových kategorí také osobní hierarchie významně se odlišující od sociálně akceptovatelné hierarchie typické v dané kultuře. Takové vzorce chování bývají dlouhodobě stabilní a nejsou omezeny na epizody duševního onemocnění. Problémy se pak objevují v adaptivní společenské aktivitě. Jako hodnoty jsou uznávány prestiž, moc, síla, sebevědomí, razance, boj, vše neadaptivní. Sociálně anetické chování těchto osob odráží nezájem o práva druhých. Spolu s nízkou frustrační tolerancí a nízkým prahem pro výbuch agresivity a násilí jsou tito lidé lhostejní ke společenským pravidlům a závazkům, morálce a zvyklostem. Typický je chladný nezájem.

\subsection{Posun hodnot do jiného obsahového rámce}

Dalším momentem, který vstupuje do patologického dění, je posunutí hodnoty do jiného obsahového rámce, často bez náhledu na nepřiléhavost takového posunu. Zpravidla se zakládá na ego-obranných mechanismech. Hodnotou je např. bezpečí dospělého muže u matky, ale navenek se stávají hodnotou politické názory maminky, za kterými stojí.

\subsection{Konflikt hodnot}

Koncepce toho, co je žádoucí, jsou spolu v různých vztazích. Mohou se překrývat, doplňo- 
vat, přecházet jedna $v$ druhou, nebo naopak vylučovat. Konflikt hodnot je vymezen např. Hnilicou ${ }^{25}$ jako situace logického sporu v koncepcích toho, co je žádoucí, a to zcela nezávisle na psychologických důsledcích tohoto sporu. Tentýž autor považuje potenciální konflikt hodnot za univerzální atribut každého hodnotového systému, protože každý systém hodnot sestává z některých hodnot, které se vylučují. Jestliže získají vylučující se hodnoty prioritní místa v hierarchii, stává se konflikt hodnot aktuálním a získává význam v eventuální dekompenzaci psychických obtíží. Přitom může být konflikt hodnot aktualizován situačně nebo může být relativně trvalou charakteristikou určité osobnosti nebo skupiny. Aktualizovaný konflikt hodnot může být více či méně vědomý a projevovat se v kognitivní oblasti. Pokud je ale v určité míře nevědomý, jako takový se projevuje spíše v emoční či volní nebo motivační sféře a jedinec nemusí být schopen jej identifikovat.

\subsubsection{Důsledky konfliktu hodnot}

Na vědomé rovině způsobuje konflikt hodnot nejistotu týkající se toho, co má být považováno za správné a žádoucí, co dělat, co si myslet, co cítit, co chtít, aby to bylo správné, jak se tvářit, co říkat, jak se oblékat. Vychází z neschopnosti identifikovat se jednoznačně s vlastními myšlenkami, názory, postoji a volbami. Tato nejistota způsobuje proměnlivost názorů a postojů a navazující závislé postoje nebo přetrvávající ambivalentní hodnocení každého relevantního názoru, emoce, snahy, cíle, aktivity a výsledku. Logickým důsledkem je nerozhodnost při nutnosti učinit volbu, stání na jednom místě, absence motivace, nejistota ohledně správnosti již učiněné volby nebo ambivalentní postoje k ní.

Hnilica (2000) specifikuje důsledky při konfliktu hodnot ${ }^{26}$ ve třech rovinách, a to na rovině emocionální, motivační a behaviorální: Emocionální důsledky konfliktu představují zvýšený výskyt záporných emocí a nepř́ijemných tenzí, snížení frekvence kladných a stenických emocí, proměnlivost emocí, nedůvěru k vlastním emocionálním reakcím s tendencí nepodléhat jim, neřídit se jimi a hledat spíše opory z cizích, "ověřených“ zdrojů. Důsledkem konfliktu hodnot $\mathrm{v}$ rovině motivace je zacílení na odstranění kognitivně-emocionálního působení konfliktu, takže nastává vyhýbání se situacím, které navozují konflikt hodnot, reorganizace priorit v systému hodnot tak, aby v čele nestály konfliktní hodnoty, odpoutávání pozornosti od zdrojů konfliktu soustředěním se na nějakou aktivitu nebo stimulaci, která je jednodušší a s daným konfliktem nesouvisí, jako např. kouření nebo poslech hudby. V některých př́ipadech jde o snahu o př́imou redukci nepř́ijemných emocí a navozování příjemných a/nebo stenických emocí převážně chemickou cestou využitím působení alkoholu nebo drog. Nepřímá redukce nepřijemných emocí a navozování př́ijemných a/nebo stenických emoci probíhá behaviorální cestou, např. terapií, relaxací, sociálními kontakty, sexem, nakupováním apod. Do daného rámce patří též vytváření behaviorálních "závazkư“, které usnadňují identifikaci s jednou z konfliktních hodnot. Jsou představitelné kategorickými morálními soudy, jednoznačně interpretovatelnými aktivitami apod. Behaviorálním důsledkem nerozhodnosti, nejistoty a ambivalentních postojů k učiněným volbám může být neustálé vracení se k učiněným krokưm, jejich opravování, zdokonalování, anulování, neschopnost dokončit určitou činnost nebo potřeba neúměrně delšího času pro rozhodování a hodnocení.

V psychopatologii se konflikty hodnot manifestují nejčastěji na rovině úzkostných poruch, příp. poruch osobnosti. Z nich typická je porucha osobnosti závislá nebo histriónská. U dlouhodobých konfliktů lze očekávat psychosomatické reakce.

25 Srov. Karel HNILICA, Konflikt hodnot a kvalita života, s. 385-403.

26 Jan PAYNE a kol., Kvalita života a zdraví, s. 300. 


\subsection{Problém hodnotové transformace}

Zásadními tématy $\mathrm{v}$ psychoterapii jsou dvě oblasti. Jednou z nich je otázka stabilizace a udržování hodnot a důslednosti v jejich udržování, druhou je otázka změn hodnot v interakci se světem v kontextu vlastního života, vyvolávající návazné otázky o obsahu a podmínkách eventuálních změn. Do obsahového rámce těchto témat se připojuje již výše zmíněný respekt k hodnotám druhého.

Hodnota je základem postoje do té míry, že změny hodnot a změny postojů probíhají zpravidla více či méně paralelně. Předmětem analytické práce s hodnotami je míra odolnosti hodnoty vůči změnám a reflexe činitelů, kteří blokují nebo omezují změnu hodnoty a následně postoje. Je-li obrana důslednosti vlastního chování velmi výrazná a hodnoty projevují mimořádnou odolnost i v situacích, kdy není zvenčí ani spontánní, ani záměrná tendence je měnit, jde v psychoterapii o porozumění obsahu hodnot a míre jejich ohrožení $z$ hlediska pacienta. Jeli významná percepční akcentuace, tj. výběr a zdůrazňování jednotlivých informací, v souladu s postoji a hodnotami, kterých si jedinec váží, a percepční negace, tj. vyhýbání se údajům, které protiřečí stávajícím postojům a hodnotám, s výraznou emoční komponentou, pak pravděpodobně tato stabilita umožňuje orientaci člověka ve složitých situacích a změna vyvolává úzkost, nejistotu, perspektivní tenzi, strach. Souvisejícími činiteli jsou osobnostní charakteristiky člověka, jeho věková kategorie, typ hodnot i skupinový nátlak, nebot' konformování člověka $\mathrm{s}$ názorem většiny napomáhá harmonizaci rozporných hodnot, at' už vhodně nebo nevhodně. Při revizi oprávněnosti daných hodnot jsou předpokladem vždy pečlivé analýzy kognitivního a emocionálního základu stanovené hodnoty. Za předpokladu určité míry žádoucnosti změny, tj. změny kongruentní, event. ego-syntonní, Cakirpaloglu ${ }^{27}$ specifikuje roviny apercepce a valorizace jako prostor pro terapeutický vstup do systému hodnot jedince při poruchách hodnocení. Odvíjejí se více od kognitivně-behaviorálního př́istupu a představují obecný výklad, při kterém jde ve své podstatě o obranné mechanismy. Otázkou zůstává, mají-li se z nějakého důvodu měnit hodnoty podle povahy zátěžové situace.

\subsubsection{Apercepce}

Při práci s hodnotami na rovině apercepce jde spíše o asimilaci jako proces přizpůsobení se stávající situaci interpretací děje na základě předešlé zkušenosti. Dobře představitelné je opoziční redefinování významu a afirmace. U redefinování významu se pracuje na změně významu mentální představy, která vyvolala určitou hodnotu spojenou s negativní emocí. Znamená to, že nový význam má redukovat negativní a vyvolat pozitivní cítění, tj. ubránit se např. pocitům zranění, méněcennosti, smutku v situaci opuštění při rozchodu s partnerem. Předefinování pomůže otevř́t se jiné alternativě, tj. např. možnosti najít partnera lepšího. Afirmace alternativní hodnoty představuje způsob, při kterém se jedinec zacílí na nastartování pozitivního myšlení tím, že nahradí frustrující hodnotu hodnotou novou. Vyvolává si tak pozitivní procesy v oblasti myšlení a usuzování a má odhodlání $\mathrm{k}$ jiné konstruktivní akci, např. při rozchodu s partnerem se otevírají nové, svobodnější možnosti, které dříve nebyly možné. Tyto dva způsoby či podoby obranných mechanismů mohou být ve svém vyhledávání aktuálně možného či chtěného spíše možnostmi práce v oblasti krizové intervence. Cílem je podpořit pacienta $\mathrm{k}$ samostatnému rozhodnutí a volbě nastolením méně bolestné alternativy. Otázkou zůstává, zda je vhodné při redefinování či afirmaci ohrožovat či devalorizovat předchozí hodnotu, a tím i jedince, který ji uznával nebo pro ni žil.

\subsubsection{Valorizace}

Terapeutický vliv na proces valorizace je uplatnitelný, jestliže emocionální a motivační problé- 
my vycházejí z aktivované hodnoty, ale interpretace vzniklé situace zůstává stejná, řekněme v normálu. Terapeutická intervence se odehrává ve třech fázích, kterými jsou devalorizace, inhibitorní hypervalorizace a nakonec restrukturalizace hodnoty. V první fázi se odebírá význam aktivované hodnotě s cílem, aby si pacient přestal vážit určité hodnoty, a tím i redukoval nepř́ijemné pocity při eventuální aktivaci stejné hodnoty. Aby v důsledku procesu devalorizace původních hodnot nedošlo $\mathrm{k}$ disociaci uvnitř osobnosti pacienta a nenastal nový konflikt, terapie inhibitorní hypervalorizací pracuje na aktivaci alternativní hodnoty, která má za cíl mj. eliminovat problematickou hodnotu. Podmínkou je, aby byla aktivována výše postavená hodnota, např. hodnota života, hodnota zdraví apod. („hlavně, že jsem naživu, hlavně, že jsem zdravýc). Cílem etapy restrukturace hodnot je pak dostat do souladu přesvědčení jedince s odpovídající hodnotou, at' už jsou přesvědčení racionální, nebo iracionální. Opírá se při tom o realizaci cílů a zkušenosti jedince.

\section{Vývoj hodnot}

V jakýchkoliv textech $\mathrm{z}$ oblasti vývojové psychologie nalezneme v různých obměnách formulované teze, že není-li nikdo, ke komu získá jedinec bazální důvěru a pozitivní vztah, nezíská ho ani $\mathrm{k}$ sobě samotnému. Z četných odkazů v textu tohoto článku vyplývá, že bez vztahu k sobě samotnému nelze uskutečňovat hodnoty. Toto je jednoznačně potvrzováno psychoterapeutickou praxí. Přirozený zdravý vývoj hodnot může být zmařen traumatem v raném dětství nebo jinou formou morální psychopatologie nebo sociální patologie. Při určitém zjednodušení se můžeme podívat na vývoj hodnot z hlediska vazby svědomí a sebehodnocení.

Popření svědomí se váže k narcistické poruše osobnosti, nedostatek svědomí pak k asociální poruše osobnosti. U obou typů je porušena schopnost vytvořit vztah ke druhému. Tyto poruchy jsou patologické dle úvahy Beckerové nejen kvůli specifickému chování, nýbrž kvưli vztahu, který jedinec $\mathrm{k}$ tomuto chování má. ${ }^{28}$ Míra, v níž funguje psychická funkce svědomí, určuje nejspíše hloubku narušeného vztahu a míru narušenosti funkce svědomí. Narcismus je definován jako nedostatek empatie a zjevná neschopnost vzít v úvahu subjektivní zkušenosti a pocity druhých. ${ }^{29}$ Není zde ochota k sebezkoumání, protože cílem pacientů je, aby chránili ideály vlastního já. Hodnotou je zidealizovaný sebeobraz a cílem je jej zachovat. Pro zachování svého sebeobrazu projektují lidé vlastní nedokonalost na druhé. Osoby s asociální poruchou osobnosti jsou typickým př́íladem těch, kteří hodnoty posunuli do jiné roviny, takže se chovají, jako by měli právo lhát, podvádět a vraždit, a jsou bez jakékoliv formy sebepochybování a sebekritiky. O druhé se zajímají kvůli sebestimulaci, budování sebelásky a/nebo hmotným hodnotám, a to při absenci lítosti nad zraňováním druhých.

\section{Závěr}

Ačkoliv text otevírá téma možností psychoterapeutické práce s hodnotami a vysvětluje psychické obtíže, které souvisejí s různými typy problematického prožívání emocí spojených s funkcí hodnocení a tvorbou hodnot, zahrnuje jen malou část rozsáhlého tématu psychoterapie a psychologie hodnot. Moderní psychoterapie často prezentuje své úsilí o neutrálnost a bezpodmínečnou akceptaci, která je nezatížená hodnotovými kategoriemi. Zároveň ale doporučuje pozitivní hodnocení a oceňování. Raban k tomuto trendu velmi otevřeně konstatu-

28 Srov. Christina BECKER, Jádro věci: Individuace jako etický proces, Brno: Emitos, Nakladatelství Tomáše Janečka, 2007, s. 82, 83.

29 Srov. Diagnostic and Statistical Manual of Mental Disorders IV, Washington, DC: American Psychiatric Association, 2000. 
je, že hodnotová svoboda v psychoterapii je mýtus a zachovávat hodnotovou zdrženlivost je nebezpečné ideologické pokušení, protože hodnoty se potom skrytě vkrádají zadními dveřmi a podprahově infiltrují terapeutický proces. ${ }^{30} \mathrm{~K}$ této části zbývá doplnit, že znát osobní hodnotové kategorie je předpokladem každé psychoterapeutické intervence v oblasti hodnot. Každá intervenční metoda a každá teorie osobnosti a vývoje implikuje hodnocení a také to, že hodnotové konflikty či divergentní hodnotová pojetí hlavních představitelů psychoterapeutického procesu - psychoterapeuta a pacienta - mohou zapříčinit, že psychoterapii nelze uskutečnit.

\section{Hodnoty a hodnocení z pohledu psychopatologie a psychoterapie}

Abstrakł Pohled na to, co jsou hodnoty, a úvaha o tom, jakou váhu má v psychoterapii diskuse o nich, je z hlediska psychoterapeutické práce záležitost poměrně aktuální, a to tím spîse, že hodnoty nacházejí svůj výraz v postojích a ideologiích jak pacientů, tak i terapeutů. Pohled na psychoterapeutickou práci s hodnotami, hodnotovým systémem a individuální hierarchií hodnot je však nejednotný. Cílem článku je podrobit analýze možnosti psychoterapeutické intervence $v$ rámci přezkoumávání jednotlivých premis hodnotového úsudku. $V$ textu je podrobněji zmíněn existenciálně analytický prístup k hodnotám, jehož výkladový rámec dovolí pochopit téma hodnot jako výchozí pro terapeutickou práci.

Klíčová slova hodnota; hodnocení; psychoterapie; smysl

\section{Values and Evaluation from the Point of View of Psychopathology and Psychotherapy}

Abstract Examining what are values and reflecting on how important the discussion concerning them is in psychotherapy is fairly acute from the point of view of psychotherapeutic work, especially since values find expression in the attitudes and ideologies of both patients and therapists. However, the views of psychotherapeutic work with values, value system and individual value hierarchies diverge. The paper aims to analyse the possibilities of psychotherapeutic intervention within the framework of examining the individual premises of value judgement. It mentions in detail the existential-analytic approach to value, whose explanatory framework allows for construing the issue of values basic for therapeutic work.

Keywords value; value judgement; psychotherapy; meaning

30 Srov. Miloš RABAN, Duchovní smysl člověka dnes: Od objektivního k existenciálnímu a věčnému, Praha: Vyšehrad, 2008, s. 163. 